\title{
Entrepreneurial Orientation and Knowledge Creation and Their Impact on Company Performance
}

\section{Franc Vidic}

$\mathrm{PhD}$, Dean of Higher Vocation Education in Biotechnical Center Naklo, Slovenia

\begin{abstract}
This paper summarizes the arguments and counterarguments within the scientific discussion on the issue of entrepreneurship and importance of knowledge. Systematization literary sources and approaches show knowledge has to become the key economic resource. Concept is based on "knowledge-based theory, which considers knowledge as the most strategically significant resource of a firm. Learning and creating knowledge can improve innovation, process effectiveness and competitive advantage. Systematization literary sources and approaches for improving firm performance indicates dependence from different factors. Better understanding of the interaction between entrepreneurial orientation and knowledge creation processes are important. Entrepreneurial orientation refers to the strategy making processes that provide organizations with a basis for entrepreneurial decisions and actions. It is a combination of five dimensions: innovation, risk taking, proactiveness, competitive aggressiveness and autonomy (Lumpkin, Dess, 1996). Knowledge creation is conceptualized as a dialectical process, in which various contradictions are synthesized through dynamic interactions between explicit and tacit knowledge in individual human minds and among individuals, the organization, and the environment.
\end{abstract}

The paper is carried out in the following logical sequences: first chapter is Introduction with basic paper information. Next chapter is Research background and hypothesis. This is theoretical background and discussion about entrepreneurial orientation, knowledge creation and firm performance. We develop three hypotheses: H1: A firm's entrepreneurial orientation is positively associated with its knowledge creation process; H2: A firm's entrepreneurial orientation is positively associated with its performance; H3: A firm's knowledge creation process is positively associated with its performance. In next chapter Research methods, we explain empirical research data, methods. This chapter follow the Analysis and results and next Discussion and conclusion. At the ends is the list of references.

Methodological tools of the research methods were SPSS 18 and EQS 6.1 software. Year of research was 1915. The object of research is the chosen SME companies (Slovenia). The paper presents the results of an empirical analysis of 195 Slovenian small and medium-sized enterprises. The research empirically confirms and supported hypotheses $\mathrm{H} 1$ and $\mathrm{H} 3$.

The results of the research can be useful to improve the knowledge and the research gap, support of the resource-advantage theory and add piece of knowledge to a mosaic of research in different countries.

Keywords: economic education, economics, education, pedagogical, pedagogy, teaching, teaching of economics.

JEL Classification: I2.

(C) The Author, 2018. This article is published with open access at Sumy State University.

\section{Introduction}

An increased number of studies have paid attention to the relationship between knowledge and entrepreneurship (Moller, 2007; Miller, Fern, Cardinal, 2007). We believe that a better understanding of the interaction between entrepreneurial orientation and knowledge creation processes impact on the company performance. With improvements in knowledge, individuals, companies and the economy can develop better skills and contribute to higher competitiveness. Our objectives are to propose an integrated framework, which links entrepreneurial orientation, knowledge creation and performance, and to set foundation for further empirical research.

This article has the following structure. The first part is theoretical background and discussion about entrepreneurial orientation, knowledge creation and performance; in the second part we make an empirical test of a 
correlation between entrepreneurial orientation and knowledge creation. The empirical test based on a sample of 195 firms collected through a questionnaire sent to entrepreneurs and executives in Slovenian SMEs.

\section{Research background and hypoteses}

Knowledge has to become the key economic resource and the dominant - and perhaps even the only - source of competitive advantage (Drucker, 2009). Labour cost became progressively less important and traditional economic concepts such as scarcity to resources and economies of scale ceased to apply in a high degree. Of all factors of production knowledge capital creates the longest lasting competitive advantage; it is based on Knowledge-based theory, which considers knowledge as the most strategically significant resource of a firm. Teece, Pisanoand Shuen (1997) and others (Morgan, Vorhies, Mason, 2009) upgraded Knowledge based theory with Theory of dynamic firms capatibility. The theory assumes that heterogeneous resources are not sufficient in the dynamic market environment(Morgan, Vorhies, Mason, 2009; Teece, Pisano, Shuen, 1997), trends, perspectives and market information must be dynamic (Busenitz, Barney, 1997 in Holcomb, Ireland, Holmes, Hitt, 2009), thinking along established routes is not sufficient (Nonaka, 1991).

The environment is changing constantly and raidly as well as the market and customers' needs (Prajogo, Ahmed, 2006). Changes in present networked, knowledge society raise new challenges to human competences (Paavaola, Hakkarainen, 2005). Audretsch (2010) adavances the knowledge society to an entrepreneurial society. The entrepreneurial society assumes the role of physical capital and entrepreneurial capital upgraded with a knowledge capital, economic growth, job creation and competitiveness in a complex environment (Audretsch, 2010). Enterprise must know what to do, how to do it, when and where to do it in order to compete successfully. Without knowledge it is impossible to compete (Korposh, Lee, Wei, Wei, 2011). Productive participation in knowledge intensive work requires that individual professionals, their communities, and organizations continuously surpass themselves, develop new competencies, advance their knowledge and understanding as well as produce innovations and create new knowledge (Paavola, Hakkarainen, 2005). Human work is more and more focused on deliberate advancement of knowledge than just on production of material things (Bereiter, 2002 in Paavola, Hakkarainen, 2005). Knowledge and innovation is widely considered a key prerequisite for achieving organizational competitiveness and sustained long-term wealth in an increasingly volatile business environment (Esterhuizen, Schutte, Toit, 2011). Organizational learning can improve innovation process effectiveness (Huang, Wang, 2011) and competitive advantage (Barsh, 2007).

\section{Entrepreneurial Orientation}

Entrepreneurial orientation (EO) refers to a firm's strategic orientation and entrepreneurial activities, which captures specific entrepreneurial decision-making styles, methods and practices (Covin, Slevin, 1989; Lumpkin, Dess, 1996). Firms with high entrepreneurial orientation tend to seek innovative and flexible means to exploit opportunities and achieve desired objectives (Khandwalla, 1997). EO reflects how a firm operates rather than what it does (Lumpkin, Dess, 1996). EO reflects the leadership skills, the integration of proactive and aggressive initiative and turning competitive environment to their advantage (Atuathene-Gima, 2001). Companies with EO have competences to respond quickly and take advantage in niche market (Zahra, Covin, 1995), they innovate and take risks in positioning new product strategy (Miller, Friesen, 1982).

EO is a multidimensional phenomenon composed of processes, structures and habits (Lumpkin, Dess, 1996). The conceptualization of EO has been the focus of systematic inquiry in literature (Miller, 1983; Covin \& Slevin, 1991; Lumpkin, Dess, 1996; Lumpkin, Cogliser, Schneider, 2009; Wiklund, 1999). The concept of entrepreneurial orientation can apply to individuals as well as organizations (Bolton, Lane, 2012; Rauch, Wiklund, Lumpkin, Frese, 2009). In our research we accept that: competitive aggressiveness, autonomy, innovation, proactiveness and willingness to take risks are five of the characteristics commonly associated with entrepreneurial orientation (Bolton, Lane, 2012; Fillis, 2010; Lumpkin, Dess, 1996; Rauch et al., 2009; Ward, 2004). Each dimension is important, but they may not be important to the same degree (Kreiser, Marino, Weaver, 2002; Lamadrid, Heene, Gellynck, 2008; Lumpkin, Dess, 2001; Rauch et al., 2009). Each dimension can be reflected complementary to the others or in conjunction with them (Lyon, Lumpkin, Dess, 2000). The dimensions of EO are expected to vary independently on a range of possible environmental and organizational factors (Kreiser et al., 2002).

Innovation is defined as: the successful generation, development and implementation of new and novel ideas, which introduce new products, processes and/or strategies to a company or enhance current products, processes and/or strategies leading to commercial success and possible marketing leadership and the creation of value 
for shareholders, driving economic growth and improving the standard of living (Katz, 2007). Risk-taking (Cantillon, 1730 in Jun, Deshoolmeester, 2006) is associated with entering in unknown field, with the involvement of their own and other resources to operate in an uncertain environment. Proactiveness is a response and an exploration of opportunities for products and services, to achieve advantages over competitors and offers adjustments for future demand. Proactivity is reflected in relation to market opportunities. Competitive aggressiveness (Lumpkin, Dess, 2001, p. 431) is reflected in the intensity of response to competitors, monitored by organizations such as the intensity of response to other bidders rivals. Autonomy (Lumpkin, Dess, 2001, p. 431 ) is defined as an independent individual or team activity, which combines the design of the vision and its implementation. It is reflected in the self-initiative to exploit opportunities (Lumpkin, Dess, 1996).

\section{Knowledge Creation}

Knowledge is the fundamental source of competitiveness and success of the company. Knowledge is formed and exists in the minds of people, for the creation of new ideasis important interaction between individuals (Davenport, Prusak, 2000; Nonaka, 1994). Nonaka, Toyama and Konno (2000) note that knowledge creation is necessarily context dependent in terms of who participate and how they participate. From the perspective of resource-advantage theory, knowledge is not easily transferred and dispersed due to its characteristics of tacitness and immobility (Grant, 1996; Hunt, Morgan, 1996). Knowledge creation (KC) process allows firms to amplify knowledge embedded internally and transfer knowledge into operational activities to improve efficiency and create business value (Nonaka, Konno, 1998; Nonaka, Takeuchi, 1995; Nonaka, Toyama, Nagata, 2000). KC may include elements of EO and market orientation, which is further converted into knowledge capital, which can be transmitted between other employees (Li, Huang, Tsai, 2008).

Corporate culture and leadership encourage people to engage in communication, collaboration and social interaction (Li, Huang, Tsai, 2009). Social cohesion provides an effective combination of knowledge from different areas of expertise (De Luca, Atuahene-Gima, 2007). Interacting with a combination of knowledge comes to the extent of good interpersonal relationships (Floyd, Lane, 2000, in De Clecq et al., 2009), based on a anatmosphere of honesty, trust and support in the organization (Kuratko et al., 2005). New insights can affect entrepreneurial behavior and allow the ability to successfully exploit opportunities (De Clecq, Dimov, Thongpapanl, 2009). Important is the quantity and quality of information to be exchanged (Birckshaw, 2000 in Williams, Lee, 2009). Entrepreneurs need to replace the existing knowledge with the new one, to recognize what is no longer optimal positioning for the organization, and develop an organization's ability to operate in tomorrow's markets (Hamel, Prahalad, 1994). It is necessary to balance between research and development (March, 1991; Renko, Carsrud, Brännback, 2009).

Based on Theory of knowledge creation, knowledge is created through a spiral process of socialization, externalization, and combination; according to Nonaka's knowledge creation (SECI) model an organization creates knowledge through a dynamic process through interactions amongst individuals and organizations, interaction between tacit and explicit knowledge (Nonaka, 1991, 1994, Nonaka, Takeuchi, 1995;Nonaka, Toyama, Konno, 2000; Lin, Lin, Huang, 2008). We call the interaction between the two types of knowledge conversion. Through the conversion process, tacit and explicit knowledge expand in both quality and quantity. In the organization, knowledge becomes or expands through a four-stage conversion process of socialization, externalization, combination, and internalization (SECI) (Nonaka, von Krogh, Voepl, 2006): (1) socialization (from tacit knowledge to tacit knowledge); (2) externalization (from tacit knowledge to explicit knowledge); (3) combination (from explicit knowledge to explicit knowledge); and (4) internalization (from explicit knowledge to tacit knowledge). In knowledge conversion, personal subjective knowledge is validated, connected to and synthesized with others' knowledge (Nonaka, Takeuchi, 1995). We can describe the model as a spiral of interactions between explicit and tacit knowledge (Nonaka, 1994; Nonaka, Konno, 1998) through continuously dynamic self-transcendental processes (Nonaka et al., 2000).

Socialization (Li, et al., 2009) is the process of converting new tacit knowledge through shared experiences. Since tacit knowledge is difficult to formalize and often time and space specific, tacit knowledge can be acquired only through shared experience, such as spending time together or living in the same environment. Socialization typically occurs in a traditional apprenticeship, where apprentices learn the tacit knowledge needed in their craft through hands-on experience, rather than from written manuals or textbooks. Firms often acquire and take advantage of the tacit knowledge embedded in customers or suppliers by interacting with them. 
Externalization ( $\mathrm{Li}$, et al., 2009) is the process of articulating tacit knowledge into explicit knowledge. When tacit knowledge is transmit to explicit, knowledge is crystallized, thus allowing it to be shared by others, and it becomes the basis of new knowledge. Concept creation in new product development is an example of this conversion process. The successful conversion of tacit knowledge into explicit knowledge depends on the sequential use of metaphor, analogy and model.

Combination ( $\mathrm{Li}$, et al., 2009) is the process of converting explicit knowledge into more complex and systematic sets of explicit knowledge. Explicit knowledge is collected from inside or outside the organization and then combined, edited or processed to form new knowledge. The new explicit knowledge is then disseminated among the members of the organization. The combination mode of knowledge conversion can also include the 'breakdown' of concepts. Breaking down a concept such as a corporate vision into operational business or product concepts also creates systemic, explicit knowledge.

Internalizations ( $\mathrm{Li}$, et al., 2009) embody explicit knowledge into tacit knowledge. Through internalization, explicit knowledge is created and shared throughout organization and converted into tacit knowledge by individuals. Internalization is closely related to learning by doing. By reading documents or manuals about their jobs and the organization, and by rejecting upon them, trainees can internalize the explicit knowledge written in such documents to enrich their tacit knowledge base (Li, et al., 2009). This tacit knowledge accumulated at the individual level can then set off a new spiral of knowledge creation when it is shared with others through socialization.

\section{Entrepreneurial Orientation and Knowledge Creation Process}

Entrepreneurial attitudes and behaviors are critical for new ventures to facilitate the utilization of new and existing knowledge to discover market opportunities (Wiklund, Shepherd, 2003). When developing EO, ventures can exploit the dynamic SECI spiral to create and share knowledge dispersed among individual members. Firms with innovativeness may have a tendency to support new ideas and novelty, and further increase the engagement in developing new products, services, or processes (Lumpkin, Dess, 1996). The development of new products and services involves extensive and intensive knowledge activities. The knowledge conversion provides value to customers and help to make competitive position in the market (Griffith, Noble, Chen, 2006). The organization creates a new combination of resources and products, intended to upcoming changes; opportunities sand entry to market and take advantage to exploit opportunities (Lumpkin, Dess, 2001).

Entrepreneurs focus on new opportunities (Lumpkin, Dess, 1996) and provide a strong motivation to move away from the firm's preexisting routines (Cui, Zheng, 2007). Highly entrepreneurial oriented firms are willing to question long-held assumptions about their mission, customers, capabilities or strategy, which is consistent with creating knowledge. They should motivate employees to take risks to deal with the challenging and creative activities. Employees need a socialization process to build more interaction to exchange tacit knowledge, solve problems, and avoid mistakes (Nonaka, Takeuchi, Umemoto, 1996; Quinn, 1992).Through externalization, employees can understand new product development and increase their involvement in activities of articulating tacit knowledge into substantial concepts and notions (Nonaka, Konno, 1998; Nonaka, Takeuchi, 1995; Nonaka, Toyama, 2005). The newly created knowledge and existing knowledge are then combined, edited, or processed to form more complex and explicit knowledge through the combination process. Innovative ideas become more usable, thereby crystallizing knowledge into new products or services (Nonaka, Konno, 1998). Internalization process promotes the actualization of new product innovation or improvement within the organization.

Grant (1996), Spender (1996) and Teece (2000) observed correlation between innovation and creating knowledge through the collection and its use in the enterprise. A high degree of entrepreneurial orientation involves long-term development guideline sand vision, mission, work with customers, setting up new capacities. Realizing the vision of entrepreneurs can be related to knowledge creation (Cui, Zheng, 2007).

According to the above, SMEs with entrepreneurial orientation are more prone to focus attention and effort towards knowledge creation process. The SECI spiral can utilize the full potential of knowledge and further facilitate its creation and utilization within the firm, which facilitates the transformation and activation of entrepreneurial orientation. We can reasonably expect the positive relationship between entrepreneurial orientation and knowledge creation process. 
Hypothesis 1: A firm's entrepreneurial orientation is positively associated with its knowledge creation process.

\section{Entrepreneurial Orientation and Firm Performance}

Researchers argue that EO is a combination of five dimensions: innovation, risk taking, proactiveness, competitive aggressiveness and autonomy (e.g. Lumpkin, Dess, 1996). Innovativeness reflects a tendency to support new ideas, novelty, experimentation, and creative processes, thereby departing from established practices and technologies (Lumpkin, Dess, 1996). Proactiveness refers to a posture of anticipating and acting on future wants and needs. Risk taking is connected with a willingness to commit large amounts of resources to projects, where the cost of failure may be high (Lyon et al., 2000). Autonomy reflects on the ability to be self-directed in the pursuit of market opportunities (Lumpkin \& Dess, 1996). EO is also committing resources to projects where the outcomes are unknown, it largely reflects the organization's willingness to break away from triedand-true and venture into the unknown (Wiklund, Shepherd, 2003). Previous empirical results provide support for positive relationship between EO and performance.

Hypothesis 2: A firm's entrepreneurial orientation is positively associated with its performance.

\section{Knowledge Creation and Firm Performance}

Knowledge creation can be frame breaking and more likely to lead to competitive advantage (Slater, Narver, 1995). It is forward looking and helps reduce the frequency and magnitude of a major shock (Day, 1994); it also helps to reduce the impression of an environmental complexity. Knowledge creation process can be focused on effectively satisfying the latent needs through new products and ways of doing business (Day, 1994). This should lead directly to an outcome, such as new product success, or improve existing products more efficiently, thereby reducing redundancies and costs (Cui, Zheng, 2007; Grant, 1996; Nonaka, 2000).In general, entrepreneurial knowledge can have positive effects on growth and profitability of companies (Gomezelj Omerzel, Antoncic, 2008; Gomezelj Omerzel, Antoncic, Ruzzier, 2011). The existing above empirical evidence regarding knowledge creation and performance indicates a positive association.

Hypothesis 3: A firm's knowledge creation process is positively associated with its performance.

\section{Research methods}

Based on the related theory and literature about EO and knowledge creation this study tries integrating two dimensions and exploring their correlation and their association to firm performance.

\section{Sample and Data Collection}

We employed a questionnaire survey approach to collect data, and all items required five-point Likert-type scales, in which responses ranged from 1 = "strongly disagree," through $3=$ "neutral," to $5=$ "strongly agree."

Sample. 2,500 questionnaires were mailed to executive managers of SMEs in Slovenia. We selected the firms with more than 6 and less than 250 employees. We asked respondents (entrepreneurs or executives) to evaluate their level of agreement with each question. 203 responses were received and eight of them were incomplete. The remaining 195 valid and complete questionnaires were used for the quantitative analysis. It represented a usable response rate of $7.8 \%$ (Table 1).

For each company, we collected data with measures of knowledge creation process, innovativeness and company performance. A principal component factor analysis on the questionnaire measurement items yielded seven factors with eingen values greater than 1.0 that accounted for $69.67 \%$ of the total variance, and factor 1 accounted for $16.46 \%$ for the variance. Since several factors, as opposed to one single factor, were identified and the first factor did not account for most of the variance, common method bias is unlikely to be a serious problem in the data (Podsakoff, Organ,1986).

Table 1. Comparison between sent and returned questionnaires according to the number of full and part-time employees

\begin{tabular}{|l|c|c|c|c|}
\hline & \multicolumn{2}{|c|}{ Sent questionnaires } & \multicolumn{2}{c|}{ Returned questionnaires } \\
\hline No.of employees & Frequency & $\begin{array}{c}\text { Percentage } \\
(\%)\end{array}$ & Frequency & $\begin{array}{c}\text { Percentage } \\
(\%)\end{array}$ \\
\hline $6-9$ & 968 & 38.72 & 57 & 28.64 \\
\hline $10-19$ & 853 & 34.12 & 62 & 31.16 \\
\hline
\end{tabular}


Table 1 (cont.). Comparison between sent and returned questionnaires according to the number of full and part-time employees

\begin{tabular}{|l|c|c|c|c|}
\hline & \multicolumn{2}{|c|}{ Sent questionnaires } & \multicolumn{2}{c|}{ Returned questionnaires } \\
\hline No.of employees & Frequency & $\begin{array}{c}\text { Percentage } \\
(\%)\end{array}$ & Frequency & $\begin{array}{c}\text { Percentage } \\
(\%)\end{array}$ \\
\hline $20-49$ & 480 & 19.20 & 46 & 23.12 \\
\hline $50-99$ & 129 & 5.16 & 24 & 12.06 \\
\hline $100-250$ & 70 & 2.80 & 10 & 5.02 \\
\hline No answer & & & $(4)$ & $199(203)$ \\
\hline Cumulative & 2,500 & 100 & & 100 \\
\hline
\end{tabular}

\section{Measures}

Entrepreneurial orientation (EO). Drawing upon previous studies (e.g. Lumpkin, Dess, 1996, 2001; Miller, 1983), entrepreneurial orientation was measured with five dimensions: innovativeness, risk-taking, proactiveness, competitive aggressiveness, and autonomy. Innovativeness refers to a willingness to support creativity and experimentation in introducing new products/services, and novelty, technological leadership and R\&D in developing new processes. Risk-taking means a tendency to take bold actions such as venturing into unknown new markets, committing a large portion of resources to ventures with uncertain outcomes, and/ or borrowing heavily. Proactiveness refers to how firms relate to market opportunities by seizing initiative in the marketplace. Competitive aggressiveness refers to how firms react to competitive trends and demands that already exist in the marketplace. Autonomy is defined as independent action by an individual or team aimed at bringing forth a business concept or vision and carrying it through to completion.

Knowledge creation process. This study used a five-point scale, adapted from Sabherwal and Becerra-Fernandez (2003), to measure knowledge creation process variable. The four dimensions of knowledge creation process were socialization, externalization, combination, and internalization (Nonaka,1994; Nonaka et al., 2000; Sabherwal \& Becerra-Fernandez, 2003). Four items measured socialization: cooperative projects across directorates, the use of apprentices and mentors to transfer knowledge, brainstorming retreats or camps, and employee rotation across areas. Five items measured externalization: a problem-solving system based on a technology like case-based reasoning, groupware and other collaboration learning tools, pointers to expertise, modeling based on analogies and metaphors, and capture and transfer of experts knowledge. Four items measured combination: web-based access to data, web pages, databases, and repositories of information, best practices, and lessons learned. Three items measured internalization: on-the-job training, learning by doing, and learning by observation.

Company performance. This study was based on the work of Murphy et al. (1996) to measure company performance variable with three sub-dimensions: efficiency, growth and profit. The respondents rated the company performance on a five-point scale in relations to competitors. Three items measured efficiency: return on investment, return on equity, and return on assets in the past three years. Similarly, three items measured growth: sale growth, employee growth, and market share growth. Three items measured profit: return on sales, net profit margin, and gross profit of margin (Murphy et al., 1996).

\section{Analysis and results}

For all items we performed descriptive analysis to establish their suitability for statistical analysis using factor analysis. Then we performed explorative and then confirmative factor analysis, and in the end we used structured modeling method to estimate the model and correlation between EO and knowledge creation in their association to performance.

Exploratory factor analysis was performed with the software package SPSS 18. Factor analysis is utilized to examine the underlying patterns or relationships for a large number of variables and to determine whether the information are condensed or summarized in a smaller set of factors or components (Hair, Black, Babin, Anderson, 2010). We checked each of the constructs. Where it was necessary, we reduced the number of variables. For factors selection were taken into account theoretical frameworks, preliminary scree test for common factor analysis criterion, the eigen value greater than 0.8 and the explained total variance.

For further analysis of the construct of EO, we kept five factors; they represent five sub-dimensions. Two of them were explained by two variables, the rest with three variables and for further analysis of the construct 
dimensions of $\mathrm{KC}$, we keep the four factors, they represent expected four sub-dimensions, one is explained by three variables and other with five variables, as we expected in accordance with the theory. In both cases Bartlet test of sphericity used to statistically verify the correlation between variables showed that the correlation matrix has significant correlations (degree of freedom $=0.000$ ) and Kaiser-Meyer-Olkin measure of sampling adequacy has a value higher than 0.80 .

All the constructs were verified with confirmatory factor analysis; we used software package EQS 6.12. EQS 6.12 provides a chi-square value, connected degree of freedom and probability value for the chi-square statistic $(\mathrm{P})$; three additional FIT indices that assess the fit of path models were used: the comparative fit index (CFI), the root mean square error of approximation (RMSEA), the Bentler-Bonett normed fit index (NFI); and reliability coefficients Cronbach's $\alpha$ (Cronbach's $\alpha$ ) and reliability coefficient (RHO).

The fit indexes of confirmatory factor analysis for the measurement models ranged from adequate to excellent: entrepreneurial orientation: Chi Sq. $=91.65$ based on 55 degrees of freedom, $\mathrm{P}=0.00, \mathrm{CFI}=0.98, \mathrm{RMSEA}$ $=0.06, \mathrm{NFI}=0.95$, Cronbach's $\alpha=0.88, \mathrm{RHO}=0.93$; knowledge creation: Chi Sq. $=242.523$ based on 129 degrees of freedom, $\mathrm{P}=0.00, \mathrm{CFI}=0.97$, RMSEA $=0.07, \mathrm{NFI}=0.94$, Cronbach's $\alpha=0.92, \mathrm{RHO}=0.94$; performance: Chi Sq. $=35.40$ based on 24 degrees of freedom, $\mathrm{P}=0.06, \mathrm{CFI}=0.99, \mathrm{RMSEA}=0.05, \mathrm{NFI}=$ 0.98 , Crombach's $\alpha=0.93, \mathrm{RHO}=0.96$.

With confirmatory factor analysis we tested how measured dimensions represent the construct to check, better understand and validate results of explorative factor analysis. We confirmed the validity of the results of the exploratory analysis.

Reliability and validity. We measured reliability of the multi-item scale for each dimension using Cronbach's alphas and composite reliabilities measures. Both measures of reliability were above the recommended minimum standard of 0.60 (Hair et al., 2010). For all twelve dimensions, measures of reliability are higher than 0.80 .

To test the hypothesized relationships between constructs in the path-analytic framework, this study employed EQS 6.12. We measured relationship model between EO and knowledge creation and their relationship to firm performance, and its convergent and discriminant validity. Thus we have proven the multidimensional model and its comparability, as most indices indicate suitability of the construct of integrated model with an excellent value (Chi sq. $=55.42$ based on 51 degrees of freedom, $\mathrm{P}=0.31, \mathrm{CFI}=0.99, \mathrm{RMSEA}=0.03, \mathrm{NFI}=0.94$, Cronbach $\alpha=0.87, \mathrm{RHO}=0.90)$. Results showed a high correlation between constructs $\mathrm{EO}$ and $\mathrm{KC}$, the value is 0.72 (Figure 1).

Table 2. Iteratively reweighted least squares solution (elliptical distribution theory; decomposition of effects with standardized values parameter effects)

\begin{tabular}{|c|c|c|c|}
\hline \multicolumn{2}{|r|}{ Standardized solution } & \multirow[t]{2}{*}{ R-squared } & \multirow{2}{*}{$\begin{array}{c}\text { Statistically significant at the } 5 \% \\
\text { level }\end{array}$} \\
\hline $\mathrm{R}$ & $=\mathrm{V} 132=1.000 \mathrm{~F} 1+1.000 \mathrm{E} 132$ & & \\
\hline $\mathrm{CA}$ & $=\mathrm{V} 133=0.904 * \mathrm{~F} 1+1.000 \mathrm{E} 133$ & 0.247 & 3.666 \\
\hline A & $=\mathrm{V} 134=1.199 * \mathrm{~F} 1 \quad+1.000 \mathrm{E} 134$ & 0.238 & 5.033 \\
\hline I & $=\mathrm{V} 135=1.337 * \mathrm{~F} 1 \quad+1.000 \mathrm{E} 135$ & 0.239 & 5.590 \\
\hline $\mathrm{P}$ & $=\mathrm{V} 136=1.662 * \mathrm{~F} 1+1.000 \mathrm{E} 136$ & 0.282 & 5.886 \\
\hline S & $=\mathrm{V} 144=1.000 \mathrm{~F} 3 \quad+1.000 \mathrm{E} 144$ & & \\
\hline $\mathrm{E}$ & $=\mathrm{V} 145=1.067 * \mathrm{~F} 3+1.000 \mathrm{E} 145$ & 0.123 & 8.672 \\
\hline $\mathrm{C}$ & $=\mathrm{V} 146=0.883 * \mathrm{~F} 3+1.000 \mathrm{E} 146$ & 0.120 & 7.372 \\
\hline I & $=\mathrm{V} 147=0.689 * \mathrm{~F} 3 \quad+1.000 \mathrm{E} 147$ & 0.110 & 6.241 \\
\hline CPE & $=\mathrm{V} 148=1.000 \mathrm{~F} 2+1.000 \mathrm{E} 148$ & & \\
\hline CPG : & $=\mathrm{V} 149=0.739 * \mathrm{~F} 2+1.000 \mathrm{E} 149$ & 0.097 & 7.604 \\
\hline CPP & $=\mathrm{V} 150=1.028 * \mathrm{~F} 2+1.000 \mathrm{E} 150$ & 0.116 & 8.879 \\
\hline
\end{tabular}

Notes: EO (entrepreneurial orientation) with sub-dimensions: R-risk-taking, C-competitive aggressiveness, A-autonomy, I-innovation, P-proactiveness; F2 - KC (knowledge creation) with sub-dimensions: S - socialization, E - externalization, C - combination, KZI internalization; $\mathrm{CP}$ (company performance): $\mathrm{CPE}$ - efficiency, CPG - growth, $\mathrm{CPP}$ - profitability. 


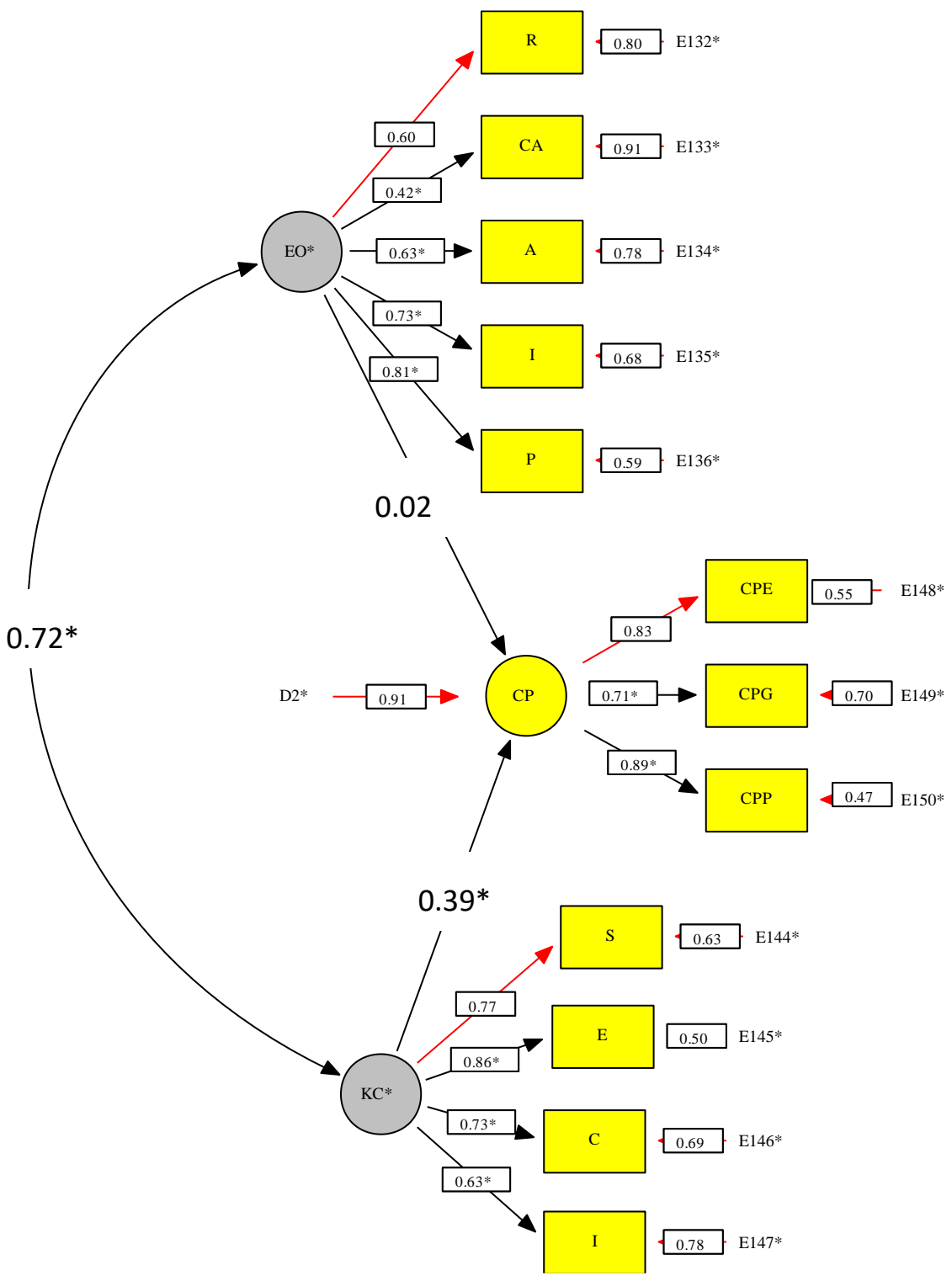

Figure 1. EQS 6.1, correlation between entrepreneurial orientation and knowledge creation and their relationship to performance

Notes: EO (entrepreneurial orientation) with sub-dimensions: R-risk-taking, CA-competitive aggressiveness, A-autonomy, I-innovation, P-proactiveness; KC (knowledge creation) with sub-dimensions: S - socialization, E - externalization, C- combination, KZI - internalization; CP (performance): CPE - efficiency, CPG - growth, CPP - profitability.

The formula of the iteratively reweighted least squares solution (elliptical distribution theory) of construct equations with standard errors and test statistics (statistically significant at the 5\% level are marked with @) is as follows:

$\mathrm{CP}=0.026 * \mathrm{EO}+0.409 * \mathrm{KC}+1.000 \mathrm{D} 2$

$0.300 \quad 0.192$

0.085 2.128@

The analysis provided some support for the study's three hypotheses (Table 3):H1: A firm's entrepreneurial orientation is positively associated with its knowledge creation process (supported), H2: A firm's entrepreneurial orientation is positively associated with its performance (not supported), and H3: A firm's knowledge creation process is positively associated with its performance (supported). Table 2 and Table 3 reports the results of standardized path estimates and Figure 1 shows the path coefficients and construct relationships. 
Table 3. Standardized paths estimated

\begin{tabular}{|c|c|c|c|}
\hline Hypothesis & Variables & Correlation coefficient & Result \\
\hline $\mathrm{H} 1$ & $\begin{array}{c}\text { A firm's entrepreneurial orientation is positively } \\
\text { associated with its knowledge creation process }\end{array}$ & 0.72 & Supported \\
\hline Hypothesis & Variables & Standardized coefficient & Result \\
\hline $\mathrm{H} 2$ & $\begin{array}{c}\text { A firm's entrepreneurial orientation is positively } \\
\text { associated with its performance }\end{array}$ & 0.02 & Not supported \\
\hline $\mathrm{H} 3$ & $\begin{array}{c}\text { A firm's knowledge creation process is positively } \\
\text { associated with it performance }\end{array}$ & 0.39 & Supported \\
\hline
\end{tabular}

\section{Discussion and conclusion}

Grant (1996), Spender (1996), Teece (2000), Watson and Helvet (2006 in Li et al., 2009) observed correlation between innovation and creating knowledge through the collection and its use in the organization. Organizations with innovative tendencies can be more inclined to exchange and use information (Altman, 1986; Von Hipp, 1988 in Williams, Lee, 2009); it is necessary to create knowledge. EO increases collection and use of information for their activities, creative and proactive orientation and to take risks (Slater, Narver, 1998; Keh et al., 2007). Hurley and Hult (1998) found a correlation between high levels of innovation to a culture of learning. In entrepreneurial firms sharing knowledge within the company may lead to the creation of new knowledge and its diffusion across an enterprise (Cohen, Levinthal, 1990). This is reflected in the use of knowledge (Li et al., 2009). EO organization often directly supports generative learning by focusing to identify and exploit new opportunities and motivates employees to move from the pressure of a routine work (Cui, Zheng, 2007). A high degree of EO involves long-term development guidelines, vision, mission, work with customers, setting up new capacities. Realizing the vision of entrepreneurs is related to the double loop learning (creating knowledge) (Cui, Zheng, 2007).

The results of the study support correlation between EO and knowledge creation and knowledge creation to firm performance. Empirical analysis supported two of the three hypotheses: H1: A firm's entrepreneurial orientation is in correlation with its knowledge creation process and H3: A firm's knowledge creation process is positively associated with its performance.

The results allow a better understanding of the development dynamics, proactive actions, knowledge creation and firm performance in a dynamic and competitive environment. Results help to improve the knowledge and the research gap, support of the resource-advantage theory and add piece of knowledge to a mosaic of research in different countries, with a survey among Slovenian companies. Finally, this study contributes to integrate the domains of entrepreneurial orientation and knowledge management research.

From a practical point of view, our study suggests that managers should be aware of the importance of KC process in the link of EO and firm performance. Managers have to facilitate dynamics and spiral of knowledge creation by taking a leading role in managing the SECI process.

Although this study provides some meaningful results for research and practice, there are several limitations (measures, sample, data collection). This study has some inherent limitations. First, our cross-sectional design prevents us from studying causal relationships among the variables. A longitudinal investigation would provide further insights into the dynamic nature of knowledge creation and different organizational levels. Future research might use longitudinal design to draw causal inferences of our model. Future research could overcome this limitation by expanding the scope of studies to include larger and older firms.

\section{References}

1. Atuahene-Gima, K., \& Ko, A. (2001).An Empirical Investigation of the Effect of Market Orientation and Entrepreneurship Orientation Alignment on Product Innovation. Organization Science, 12 (1), 54-74.

2. Atuahene-Gima, K., Slater, S.F., \& Olson, E.M. (2005).The Contingent Value of Responsive and Proactive Market Orientations for New Product Program Performance. Journal of Product Innovation Management, 22 (6), 464-482.

3. Audretsch, D.B. (2010). The Entrepreneurial Society. In D.B., Audretsch, G., Battista Dagnino, R. Faraci, \& R.E, Hoskisson (ur.), New Frontiers in Entrepreneurship, International Studies in Entrepreneurship. New York: Springer. 
4. Barsh, J. (2007). Innovation Management: A Conversation with Gary Hamel and Lowell Bryan. The McKinsey Quarterly, 3, 1-10.

5. Bereiter, C. (2002). Education and Mind in the Knowledge Age. Erlbaum, Hillsdale, NY.

6. Bolton, D. L., \& Lane, M.D. (2012). Individual Entrepreneurial Orientation: Development of a Measurement Instrument. Education and Training, 54 (2), 219-233.

7. Burgelman, R.A. (1983). Designs for Corporate Entrepreneurship in Established Firms. California Management Review, 26 (3), 154-166.

8. Capedaa, G., \& Vera, D. (2007). Dynamic Capabilities and Dynamic Capabilities: A Knowledge Next Term Management Perspective. Journal of Business Research, 60, 426-437.

9. Covin, J.G., \& Slevin, D.P. (1989). Strategic Management of Small Firms in Hostile and Benign Environments. Strategic Management Journal, 10, 75-87.

10. Cui, Yi, \& Zheng, X. (2007). An Integration and Empirical Examination of Entrepreneurial Orientation, Marketing Orientation and Firm Performance. Wireless Communications, Networking and Mobile Computing. WiCom.

11. Davenport, T., \& Prusak, L. (2000). Working Knowledge: How Organizations Manage, What they Know. Boston: Harvard Business School Press.

12. Day, G.S. (1994). The Capabilities of Market Driven Organization. Journal of Marketing, 58, 37-52.

13. De Clercq, D., Dimov, D., \& Thongpapanl, N. (2009). The Moderating Impact of Internal Social Exchange Processes on the Entrepreneurial Orientation - Performance Relationship. Journal of Business Venturing, 17.

14. De Luca, L.M., \& Atuahene-Gima, K. (2007). Market Knowledge Dimensions and Cross-Functional Collaboration: Examining the Different Routes to Product Innovation Performance. Journal of Marketing, 71, 95-112.

15. Drucker, P.F. (2009). A Century of Social Transformation: Emergence of Knowledge Society. In Managing in a Time of Great Change. Boston: Harvard Business Press, 177-230.

16. Essmann, H.E. (2009). Toward Innovation Capatibility Maturity. Ph.D. Thesis, University of Stelenbosch.

17. Esterhuizen, D., Schutte, C.S.L., \& du Toit, A.S.A. (2011). Knowledge Creation Process as Critical Enablers for Innovation. International Journal of Information Management.

18. Fillis, I. (2010). The Role of Creativity in Entrepreneurship. Journal of Enterprising Culture, 18(1), 49-81.

19. Fischer, M.M., \& Fröhlich, J. (2001). Knowledge Complexity and Innovation System. Springer.

20. Gomezelj Omerzel, D., Antoncic, B. (2008). Critical Entrepreneur Knowledge Dimensions for the SME Performance. Industrial Management \& Data Systems, 108(9), 1182-1199.

21. Gomezelj Omerzel, D., Antoncic, B., \& Ruzzier, M. (2011). Developing and Testing a Multi-Dimensional Knowledge Management Model on Slovenian SMEs. Baltic Journal of Management, 6(2), 179-204

22. Gray, B. (2000). Knowledge Management Overview. Irwine, CA: University of California.

23. Grant, R.M. (1996). Toward a Knowledge-Based Theory of the Firm. Strategic Management Journal, 17, 93-107.

24. Griffith, D.A., Noble, S.M., \& Chen, Q. (2006). The Performance Implications of Entrepreneurial Proactivity: A Dynamic Capabilities Approach. Journal of Retailing, 82(1), 51-62.

25. Hair, J.F., Black, W.C., Babin, B.J., \& Anderson, R.E. (2010). Multivariate Data Analysis (7th ed.). Upper Saddle River, NY: Pearson-Prentice Hall Publisher.

26. Hamel, G., \& Prahalad, C.K. (1994). Competing for the Future. Boston: Harvard Business School Press.

27. Hart, S.L. (1992). An Integrative Framework for Strategy-Making Processes. Academy of Management Review, 17(2), 327-351.

28. Hoegl, M., \& Shulze, A. (2005). How to Support Knowledge Creation in New Product Development: An Investigation Methods. European Management Journals, 23 (3), 263-273.

29. Huang, S.K., \& Wang, Y.L. (2011): Entrepreneurial Orientation, Learning Orientation and Innovation in Small and Medium Enterprises. Procedia Social and Behavioural Sciences, 24, 463-570.

30. Hunt, D.S., \& Morgan, R.M. (1995). The Comparative Advantage of Competition. Journal of Marketing, $59,1-15$.

31. Jun, Z., \& Deschoolmeester, D. (2006). Exploring Entrepreneurial Orientation (EO) in 3 Dimensions: A New Prospective for Analyzing the Value of a Company. Available at: http://www.kmu.unisg.ch/rencontres/RENC2004/Topics/Deschoolmester_Renc_04_Topic_D.pdf (Accessed 15.12.2008).

32. Katz, B. (2007). Integration of Project Management Processes with Methology to Manage Radical Innovation Project. M. Sc. Disertation University of Stelenbosch.

33. Khandwalla, P.N. (1997). The Design of Organizations. Harcourt Brace Jovanovich, Inc.: New York. 
34. Kleinsmann, M., Buijs, J., \& Valkenburg, R. (2010). Understanding the Complexity of Knowlege Integration in Collaborative New Product Development Teams: ACase Study. Journal of Engineering and Technology Management, 27(1-2), 20-32.

35. Korposch, D., Lee, Y.C, Wei, C.C., \& Wei, C.S. (2011). Modelling the Effects of Existing Knowledge on cCreation of New Knowledge. Concurrent Engineering: Research and Applications, 19(3), 225-233.

36. Kreiser, P., Marino, L., \& Weaver, M.K. (2002). Assessing the Relationship Between Entrepreneurial Orientation, the External Environment, and Firm Performance. Frontiers of Entrepreneurship Research. Babson. Available at: http://www.babson.edu/entrep/fer/BABSON2002/X/X_P3/P3/html/x-p3.htm (Accessed 4.2.2009).

37. Lamadrid, R., Heene, A., \& Gellynck, X. (2008). Rewiring Business Firms Through an Entrepreneurial Oriented Strategy. Working Paper. Faculteit Economie en Edrijfskunde.

38. Li, Y.H., Huang, J.W., \& Tsai, M.T. (2009). Entrepreneurial Orientation and Firm Performance: the Role of KnowledgeCreation Process. Industrial Marketing Management, 38, 440-449.

39. Li, Y, Liu, X., Wang, L., Li, M., \& Guo, H. (2009). How Entrepreneurial Effect on Knowledge Management on Innovation. System Research and Behavioural Science, 26, 645-660.

40. Lin, F., Lin, S. \& Huang, T. (2008). Knowledge Sharing and Creation in Teachers Professional Virtual Community. Computers and Education, 50, 742-765.

41. Lumpkin, G. T., Cogliser, C. C., \& Schneider, D. R. (2009). Understanding and Measuring Autonomy: An Entrepreneurial Orientation Perspective. Entrepreneurship Theory and Practice, 33(1), 47-69.

42. Lumpkin, G.T., \& Dess G.G. (2001). Linking Two Dimensions of Entrepreneurial Orientation to firm Performance: The Moderating Role of Environment and Industry Life Cycle. Journal of Business Venturing, 16(5), 429-451.

43. Lumpkin, G.T., \& Dess, G.G. (1996). Clarifying the Entrepreneurial Orientation Construct and Linking it to Performance. Academy of Management Review, 21 (1), 135-172.

44. Lyon, W.D., Lumpkin, G.T., \& Dess G.G. (2000). Enhancing Entrepreneurial Orientation Research: Operationalizing and Measuring a Key Strategic Decision Making Process. Journal of Management, 26(5), 1055-1085.

45. Malone, D. (2002). Knowledge Management: A Model for Organizational Learning. International Journal of Accounting Informational Systems, 3(2), 111-123.

46. McAdam, R. (2004). Knowledge Creation and Idea Generation: A Critical Quality Perspective. Technovation, 24, 697-705.

47. Miller, D. (1983). The Correlates of Entrepreneurship in Three Types of Firms. Management Science, 29 (7), 770-791.

48. Miller D.J., Fern, M.J., \& Cardinal, L.B. (2007). The Use of Knowledge for Technological Innovation Within Diversified Firms. Academy of Management Journal, 50, 308-326.

49. Moller C. (2007). Process Innovation Laboratory: A New Approach to Business Process Innovation Based on Enterprise Information Systems. Enterprise Information Systems, 1(1), 113-128.

50. Morgan, N.A., Vorhies, D.W., \& Mason, C.H. (2009). Market Orientation, Marketing Capabilities and Firm Performance. Strategic Marketing Journal, 30, 909-920.

51. Murphy, G. B., Trailer, J. W., \& Hill, R. C. (1996). Measuring Performance in Entrepreneurship Research. Journal of Business Research, 36(1), 15-23.

52. Nonaka, I., \& Toyama, R. (2005). The Theory of the Knowledge Creation Firm: Subjectivity, Objectivity, and Synthesis. Industrial and Corporate Change, 14(3), 419-436.

53. Nonaka, I., von Krogh, G. \& Voepel, S. (2006). Organizational Knowledge Creation: Evolutionary Paths and Future Advances. Organization Studies, 27 (8), 1179-1208.

54. Paavola, S., \& Hkkarainen, K. (2005). The Knowledge Creation Metaphor: An Emergent Metaphor Epistemological Approach to Learning. Science \&Education, 14, 535-557.

55. Prajogo, D.I., \& Ahmed P.K. (2006). Relationships Between Innovation Stimulus, Innovation Capacity, and Innovation Performance. $R \& D$ Management, 36 (5), 499-515.

56. Quinn, J. B. (1992). Intelligent Enterprise: A Knowledge and Service - Based Paradigm or Industry? New York, NY: The Free Press.

57. Rauch, A., Wiklund, J., Frese, M., \& Lumpkin, G.T. (2009).Entrepreneurial Orientation and Business Performance: An Assessment of Past Research and Suggestions for the future. Entrepreneurship Theory and Practice, 33 (3), 761-787. 
58. Sabherwal, R., \& Becerra-Fernandez, I. (2003). An Empirical Study of the Effect of KnowledgeManagement Processes at Individual, Group, and Organizational Levels.Decision Sciences, 34 ( 2), 225-260.

59. Samaddar, S., \& Kadiyala, S.S. (2006).An Analysis of Interorganizational Resource Sharing Discusion in Collaborative Knowledge Creation. European Journal of Operational Research, 170, 192-210.

60. Slater, S.F., \&Narver, J.C. (1995). Market Orientation and the Learning Organization. Journal of Marketing, 59(3), 28-38.

61. Spender, J.C. (1996). Making Knowledge: The Basis of Dynamic Theory of a Firm. Strategic Management Journal, 17, 45-62.

62. Teece, D.F. (2000). Strategies for Managing KnowledgeAssets: The Role of Firm Structure and Industrial Context. Long Range Planning, 33, 35-54.

63. Teece, D.J., Pisano, G., \& Shuen, A. (1997). Dynamic Capabilities and Strategic Management. Strategic Management Journal, 18 (7), 509-535.

64. Tsai, M.T. \& Li, Y.H. (2007). Knowledge Creation in New Venture Strategy and Performance.Journal of Business Research, 60, 371-381.

65. Von Krogh, G., Ichijo, K., \& Nonaka I. (2000). Enabling KnowledgeCreation: How to Unlock the Mystery of Tacit. Oxford University Press, 292.

66. Williams, C., Lee, S.H. (2009). Resource Allocations, KnowledgeNetwork Characteristics and Entrepreneurial Orientation of Multinational Corporations. ResearchPolicy, 30, 1376-1387.

67. Wiklund, J. (1999). The sustainability of the entrepreneurial orientation-performance relationship. Entrepreneurship Theory and Practice, 37-48.

68. Wiklund, J., \& Shepherd, D. (2003). Knowledge-based Resources, Entrepreneurial Orientation, and the Performance of Small and Medium-sized Businesses. Strategic Management Journal, 7 (24), 1307-1314.

69. Zahra, S. A., \& Covin, J. G. (1995). Contextual Influences on the Corporate Entrepreneurship Performance Relationship: A Longitudinal Analysis. Journal of Business Venturing, 10 (3), 43-58.

70. Zhang, Q., Lim, J., \& Cao, M. (2004). Innovation- Driven Learning in New Product Development: A Conceptual Model. Industrial Management \& Data Systems, 104(3), 252-261. 